\title{
Journal of Environmental Assessment Policy and Management FLOOD MANAGEMENT CONSIDERATION IN SUSTAINABILITY APPRAISAL AND STRATEGIC ENVIRONMENTAL ASSESSMENT IN ENGLAND AND SCOTLAND

\author{
--Manuscript Draft--
}

\begin{tabular}{|c|c|}
\hline Manuscript Number: & JEAPM-D-13-00026R1 \\
\hline Full Title: & $\begin{array}{l}\text { FLOOD MANAGEMENT CONSIDERATION IN SUSTAINABILITY APPRAISAL AND } \\
\text { STRATEGIC ENVIRONMENTAL ASSESSMENT IN ENGLAND AND SCOTLAND }\end{array}$ \\
\hline Keywords: & strategic environmental assessment; Sustainability Appraisal; flood risk management \\
\hline \multicolumn{2}{|c|}{$\begin{array}{l}\text { Corresponding Author Secondary } \\
\text { Information: }\end{array}$} \\
\hline \multicolumn{2}{|c|}{ Corresponding Author's Institution: } \\
\hline \multicolumn{2}{|c|}{ First Author Secondary Information: } \\
\hline \multirow[t]{3}{*}{ Order of Authors: } & Samuel Hayes, PhD \\
\hline & Adam Barker \\
\hline & Carys Jones, PhD \\
\hline \multicolumn{2}{|c|}{ Order of Authors Secondary Information: } \\
\hline Abstract: & $\begin{array}{l}\text { The impact of flood events in the UK has drawn attention to limitations associated with } \\
\text { traditional flood defence regimes. In recognition of this there has been a significant } \\
\text { level of advocacy for a systems based approach which assumes a greater role for } \\
\text { spatial planning. This paper considers the extent to which strategic assessment } \\
\text { contributes toward the consideration of flooding within spatial planning. The paper } \\
\text { draws on four cases from England and Scotland. Specific attention is given to the } \\
\text { nature of flood management approaches considered in assessment and the } \\
\text { recommendations presented. The research indicates that assessment practice is } \\
\text { dominated by probabilistic calculations of flood risk and typically replicates national } \\
\text { policy and guidance on flood management. It is argued that there exists potential for } \\
\text { assessment to foster more nuanced and tailored consideration of flood management } \\
\text { by including multiple perspectives, such as management of the whole system, risk and } \\
\text { vulnerability, resilience and adaptation. }\end{array}$ \\
\hline Response to Reviewers: & See separate file. \\
\hline
\end{tabular}




\section{FLOOD MANAGEMENT CONSIDERATION IN SUSTAINABILITY APPRAISAL AND STRATEGIC ENVIRONMENTAL ASSESSMENT IN ENGLAND AND SCOTLAND}

\section{SAMUEL HAYES}

University of Liverpool, Department of Geography and Planning, School of Environmental Sciences, University of Liverpool, 74 Bedford Street South, Liverpool L69 7ZQ, UK

samuel.hayes@liverpool.ac.uk

\section{ADAM BARKER}

University of Manchester, School of Environment and Development, Humanities Bridgeford Street

Building, University of Manchester, Oxford Road, Manchester M13 9PL, UK

adam.barker@manchester.ac.uk

\section{CARYS JONES}

University of Manchester, School of Environment and Development, Humanities Bridgeford Street Building, University of Manchester, Oxford Road, Manchester M13 9PL, UK carys.jones@manchester.ac.uk

The impact of flood events in the UK has drawn attention to limitations associated with traditional flood defence regimes. In recognition of this there has been a significant level of advocacy for a systems based approach which assumes a greater role for spatial planning. This paper considers the extent to which strategic assessment contributes toward the consideration of flooding within spatial planning. The paper draws on four cases from England and Scotland. Specific attention is given to the nature of flood management approaches considered in assessment and the recommendations presented. The research indicates that assessment practice is dominated by probabilistic calculations of flood risk and typically replicates national policy and guidance on flood management. It is argued that there exists potential for assessment to foster more nuanced and tailored consideration of flood management by including multiple perspectives, such as management of the whole system, risk and vulnerability, resilience and adaptation.

Key words: Strategic Environmental Assessment, Sustainability Appraisal, flood risk management 


\section{Introduction}

Over the last decade Europe has witnessed a significant increase in the number of adverse impacts generated by natural hazards. Along with storm activities, flooding is currently one of the most damaging and costly hazard-related events (European Environment Agency, 2010; Greiving et al., 2006; Kundzewicz et al., 2012; Wilby et al., 2008). Data provided by EM-DAT (2010) show that between 1998 and 2009 flooding in Europe led to direct economic losses of over EUR 60 billion. The UK is one of several areas within Europe which have been particularly adversely affected by flooding in recent years. Although it is too early to assess the consequences of the winter floods of 2013-14 in Southern England, experiences drawn from the flood events of 2007 serve to highlight the scale of impact associated with major flooding events. Damage caused by the 2007 floods alone cost the UK over $£ 3$ billion whilst 7,000 members of the public had to be rescued and thirteen people lost their lives (Hardaker \& Collier, 2013). Whilst there is growing concensus that such events are likely to be, at least in part, a result of climate change (Evans et al., 2008; Feyen et al., 2012; Rosenzweig et al., 2007), it is also apparent that flood events have been exacerbated by prevailing social and institutional responses towards natural hazards (Baan \& Klijn, 2004; Wheater \& Evans, 2009).

One of the main failings of traditional approaches to flood management in the UK has been an overemphasis on project-by-project intervention and a belief in the ability to defend against hazards through structural means (Johnson et al., 2007). The consequence of this has been the development of overly fragmented approaches to management and a failure to appreciate the interactions which exist within flooding systems (Government Office for Science, 2004; Hall \& Solomatine, 2008; Samuels et al., 2006). This has proven to be a particular problem in urban areas where the linkages between pluvial flooding, storm water and urban drainage processes have not been adequately addressed by design solutions (Dawson et al., 2008; Douglas et al., 2010; Richards et al., 2008). It has also done little to encourage wider appreciation of the inequalities associated with flooding. Several authors have indicated that certain groups within society, notably the elderly and those in lower income brackets, are especially vulnerable during flooding episodes (Baan \& Klijn, 2004; Hall et al., 2003; Klijn et al., 2004; Walker \& Burningham, 2011; Werritty et al., 2007). Yet despite this, dominant interpretations of flood management have not sufficiently accounted for issues of 'fairness' and ‘justice' amongst possible victims of flooding (Johnson et al., 2007).

These issues have been further compounded by competing institutional agendas. Local Authorities, under pressure to meet national housing targets, have frequently gone against the advice of the 
Environment Agency regarding urbanisation of floodplain locations (Howe \& White, 2004; Wheater \& Evans, 2009). Research by the Committee on Climate Change (CCC) (2012) highlighted that 21,000 homes and businesses are built annually within floodplain areas, accounting for $13 \%$ of all new development. Not only does this form of development increase household vulnerability, it serves to intensify run-off and reduce the capacity for effective flood water storage (White \& Richards, 2007).

In response to an awareness of these limitations, the last few years have witnessed a notable shift in attitudes towards flood management policy in the UK. Both the Pitt review (Evans et al., 2008) and the Department for Environment, Food and Rural Affairs (DEFRA) (2005) have drawn attention to the need to achieve a shift from incremental models based on economic costing, to a risk based approach centred on the strategic coordination of an integrated portfolio of responses. In parallel with emerging approaches elsewhere in Europe (see for example Klijn et al., 2004; Samuels et al., 2006), this shift is characterised by the transition from a paradigm based on 'keeping water out' to one based on 'living with water' (Howe \& White, 2004; Johnson \& Priest, 2008).

In response to this change, there has been a significant level of advocacy for the role that spatial planning can make in driving forward the new approach. In particular, a number of authors have commented on the potential of the planning system to act as a key mechanism for portfolio coordination and management (Greiving et al., 2006; Werritty et al., 2007; Wheater \& Evans, 2009; Wilson, 2007). As the planning system is charged with the responsibility for establishing strategic visions for sustainable development across discrete spatial scales, it is ideally placed to take a lead role in the assessment and management of flood system interactions and needs. Such an approach can not only assist in steering development to less vulnerable locations, but it can identify areas suitable for water movement and storage (Pottier et al., 2005; Vis et al., 2003; White \& Richards, 2007). This latter contribution is a central component of what White (2010) referred to as the transition to the 'absorbent city'. Here it is argued that the city is no longer to be protected from flooding but that it instead becomes a central component of the flooding system.

The contribution that spatial planning can make toward the management of flood risk has recently been formalised in England through the National Planning Policy Framework (NPPF) (DCLG, 2012) and in Scotland through the draft Scottish Planning Policy (Scottish Government, 2013a). In each case, policy provisions require Local Authorities to account for flood risk within spatial plans and to establish policies dedicated to the management of flood risk from all sources. Under the terms of EU Directive 2001/42/EC (SEA Directive), these plans are ultimately subject to strategic environmental assessment (SEA). Carter et al. (2009) have noted that the relationship between SEA and the spatial planning process affords significant potential for enhancing the contribution of spatial planning to 
flood risk management. Specifically, it is seen as an effective mechanism for the consideration of management alternatives, cumulative and indirect effects, and mitigation measures (Brown \& Therivel, 2000; Fischer, 2007). Whilst the SEA process is centred on the extent to which strategic proposals accord with objectives, its most valued function is arguably its ability to encourage policy, plan, or programme improvements (Pope et al., 2004; Sadler \& Verheem, 1996; Therivel, 2004). However, whilst there is a growing body of literature which seeks to review the performance of spatial planning in addressing flood risk (see for example Johnson \& Priest, 2008; Richards et al., 2008; White, 2010), there is a notable absence of research which investigates the wider role served by SEA.

In recognition of this, the paper aims to assess the treatment of flood risk within SEAs carried out for spatial plans in England and Scotland ${ }^{1}$. The paper is structured into six parts. In the next part of the paper we outline the main regulatory provisions which seek to promote reforms within the planning systems. We then review the potential contribution of SEA with reference to recent practice based trends. Here, we refer specifically to the contribution that SEA can make in dealing with issues of complexity and uncertainty. We then briefly introduce the methodological approach adopted before providing a detailed overview of the case study experiences. Finally we summarise the main research findings and present conclusions and possible future developments.

\section{Living with water: towards a new role for spatial planning}

Although the shift in emphasis from 'keeping water out' to 'living with water' represents a major paradigm shift in ; policy on the management of flood risk within Europe, there has been a significant degree of consensus on the main tenets of the new approach (Johnson \& Priest, 2008; Samuels et al., 2006). Whilst this has partly resulted from a shared recognition of the main drivers of flood risk, this has also resulted from attempts by scholars to reconceptualise flood management needs. In broad terms, this enables us to identify three core elements at the centre of the new approach:

i. Management of the whole system: Involves the development of strategic awareness of interactions between flood system components. A whole system approach recognises the physical attributes of the catchment (including natural and man-made components);

\footnotetext{
${ }^{1}$ The requirements of the SEA Directive are legislated for and fulfilled differently in England and Scotland through processes referred to as Sustainability Appraisal (SA) and Strategic Environmental Assessment (SEA) respectively. The two systems and the implications for this paper are discussed in greater detail in the section Enhancing delivery through SEA.
} 
socio-economic and environmental assets; and statutory organisations responsible for flood management and wider interested parties (Douglas et al., 2010; Hall et al., 2003; Pitt, 2008). As part of this approach an increased emphasis is placed upon integrated urban drainage management and the role of Sustainable Urban Drainage Systems (SUDS) (Dawson et al., 2008; DEFRA, 2005; Hall \& Solomatine, 2008; Wheater \& Evans, 2009).

ii. Risk and vulnerability: The new approach asserts an emphasis on flood risk management rather than flood defence (Merz et al., 2010; Samuels et al., 2006). This involves recognition that flood hazards need to be distinguished from flood risk. Here, hazards are seen as natural phenomena. Risk, on the other hand, relates to the potential impact of flood hazards upon vulnerable communities (Baan \& Klijn, 2004; Johnson et al., 2007; Tunstall et al., 2004). The implications of this approach are twofold. Firstly it gives a new prominence to the potential inequalities of flooding events. Secondly, it allows for a varied approach where areas of low risk can be identified as locations which, in certain situations, can accept flood water.

iii. $\quad$ Resilience and adaptation: The notion of 'living with water' brings with it a change in goals for flood management. The approach seeks not to avoid flooding but to identify the extent to which flooding can be tolerated. This requires the advancement of resilient systems (de Bruijn, 2004; White \& Richards, 2007). Crucially however, resilience in this context it is not taken as a measure of the degree to which a system can absorb impact without alteration, rather it focuses on the matter in which a system can adapt to absorb change whilst retaining its broad system characteristics (Johnson \& Priest, 2008; Vis et al., 2003).

Arguably this convergence in thinking has been a major driver of policy reform across Europe (Mostert \& Junier, 2009; Richards et al., 2008). In England, the transition to flood risk management was articulated in the publication 'Making Space for Water' (DEFRA, 2005). This document asserted the need to develop management responses which recognised the need for adaptation, particularly in the face of climate change, across catchments and shoreline systems. Underpinning this increased emphasis on integrated system management was a commitment to advancing an awareness of risk through improved data acquisition and mapping. Crucially, the new strategy asserted a greater role for spatial planning and argued for policy amendments. These were initially outlined in Planning Policy Statement 25 (DCLG, 2009b) and are now firmly embedded within the current NPPF (DCLG, 2012). Section 10 of the NPPF (ibid.) requires Local Planning Authorities to steer development away from areas of highest flood risk and most notably, states that local spatial plans must now be accompanied by a Strategic Flood Risk Assessment (SFRA). This approach, which makes use of Sequential and Exception Tests (Box 1), seeks to assess area based flood risk with a view to aligning development trajectories with an awareness of the changing nature of flood system dynamics. The 
NPPF also calls for Local Planning Authorities to protect land required for future flood management and to consider the relocation of development where risk is likely to increase over time. Similar provisions are established for Scotland with the draft Scottish Planning Policy (Scottish Government, 2013a) statement also advocating the use of the SFRA approach to guide planning decisions.

The extent to which the spatial planning system can respond effectively to this policy agenda will depend largely on an ability to deal with increased levels of spatial complexity. Holling (2001) holds that the management of complex problems requires communication frameworks which are dynamic, prescriptive in ambition and which recognise the role played by uncertainty. Arguably, these requirements are at odds with approaches which have historically addressed flood management through the use of narrow, probabilistic datasets. In many cases, these approaches have responded to uncertainty by over-stating the confidence which can be attached to predictions - so called false precision (Scott et al., 2013; White, 2010). On this basis, spatial planners need to advance approaches which are both precautionary and adaptive.

Box 1: The use of risk based testing within spatial planning

The Sequential Test: The test is part of a new risk based approach and seeks to guide development to areas of lowest flooding probability. Development should not be planned for or permitted if there are available sites appropriate for development with lower levels of flood risk. The sequential test should be applied in areas known to be at risk from flooding and should make use of the SFRA.

The Exception Test: If after having applied the Sequential Test, it is not possible to allocate development within areas of lower flooding probability, the Exception Test can be applied. To do this two criteria have to be demonstrated 1) that development provides sustainability benefits that outweigh flood risk 2) that the development is both resilient and resistant to flooding and that it prioritise the use SUDS.

(Source: DCLG, 2012)

\section{Enhancing delivery through strategic environmental assessment}

Although SEA has long been recognised as a valuable mechanism for evaluating environmental change scenarios (Bond \& Morrison-Saunders, 2009; Brown \& Therivel, 2000; Fischer, 2007), awareness of its potential effectiveness as an adaptive approach to environmental management owes much to the challenges brought by climate change. Davoudi et al. (2009) and Wilson and Piper (2010) have noted that the increasingly 'wicked' nature of problems brought about by climate change have served to promote frameworks which can account for complex system interactions and uncertain futures. As SEA is grounded in the holistic review of options, it is particularly well placed to assist in 
the development of climate change responses. A number of authors have drawn attention to the contribution that SEA can make in the planning and management of climate change problems (Larsen et al., 2013; Noble \& Christmas, 2008; Posas, 2011). These include:

i. enhancing awareness of environmental system characteristics and processes;

ii. assessing the potential direct, indirect and cumulative impacts of alternative options and scenarios;

iii. encouraging problem solving through the advancement of mitigation and monitoring provisions;

iv. establishing a framework for multi-actor participation and consultation; and

v. embedding environmental awareness and accountability within lead institutions.

The transposition of these benefits into current flood management regimes would arguably help overcome many of the limitations characteristic of previous approaches. Carter et al. (2009) have noted that because SEA seeks to maintain a close relationship with the subject of assessment, many of these benefits can translate directly into the improved consideration of flood risk issues within spatial planning. Here the role played by SEA is not necessarily one of environmental advocacy, but rather as a means of guiding the planning process towards the balanced consideration of sustainable development options (Elling, 2008; Morrison-Saunders \& Fischer, 2006; Sheate et al., 2003).

The extent to which the UK spatial planning system can effectively integrate SEA processes into the consideration of flood risk will largely depend upon an ability to reshape traditional knowledge and skill sets. This is likely to be all the more variable as approaches to SEA within the UK are different, with Sustainability Appraisal (SA) in England and SEA in Scotland. It is useful therefore to briefly consider the differences between SA and SEA. Therivel et al. (1992) defined SEA as;

the formalised, systematic and comprehensive process of evaluating the environmental impacts of a policy, plan or programme and its alternatives, including the preparation of a written report of the findings of that evaluation (Therivel et al., 1992, p.19-20).

This definition, along with others (see for example Sadler \& Verheem, 1996, p.27), suggests possible common characteristics of SEA - framing SEA as a process involving distinctive stages, identifying policies, plans and programmes as the focus and highlighting that SEA should consider environmental consequences or impacts. SA, like SEA, can take several forms and has been defined in various ways (Pope et al., 2004). Gibson (2006) highlighted that the concept of sustainability is essentially about integration and affirmed that SA should reflect this. Smith and Sheate (2001) argued that SA can be seen as a shift towards integrated assessment and decision making, as consideration is given to social, 
economic and environmental implications. This is the primary difference between SA and SEA, the inclusion of a wider breadth of topics within SA.

Related to this distinction, and arguably the most fundamental criticism of SA, is the potential marginalisation of environmental considerations through the inclusion of social and economic factors and the possible curtailment of the benefits achievable from a more environment focused form of SEA (Carter et al., 2003; Morrison-Saunders \& Fischer, 2006; Scrase \& Sheate, 2002; Sheate et al., 2003). Morrison-Saunders and Fischer (2006) identified poorly defined objectives for testing sustainability as problematic, particularly highlighting that often only economic objectives are sufficiently defined to be useful and environmental objectives are open to considerable interpretation. Given the potential difference in breadth between SA and SEA in England and Scotland this paper considers the influence of this on how flood risk is considered. Specifically, whether including social and economic factors within SA in England introduces potential for marginalisation or allows for a more holistic consideration of flood risk.

The primary legislation driving SEA in the European Union is the SEA Directive, Directive 2001/42/EC on the assessment of the effects of certain plans and programmes on the environment. The consideration of issues related to water is listed in Annex I of the SEA Directive as information to be included within an environmental report. Variation in transposition of the SEA Directive requirements has arisen in the UK as powers in this respect are devolved to the four administrations of England, Northern Ireland, Scotland and Wales (Jackson \& Illsley, 2007).

In England, The Environmental Assessment of Plans and Programmes Regulations 2004 transpose the requirements of the SEA Directive into English planning and the Planning and Compulsory Purchase Act 2004 requires 'an appraisal of the sustainability' of Core Strategies ${ }^{2}$ (UK Government, 2004, p.4). Policy states that SA is expected to cover the requirements of the SEA Directive (DCLG, 2012). Guidance on SA in England encourages the use of objectives to drive SA and specifically lists the consideration of water and flooding when setting SA objectives (DCLG, 2009a, 2014; ODPM, 2005). In Scotland the primary legislation requiring SEA of Local and Strategic Development Plans ${ }^{3}$ is The Environmental Assessment (Scotland) Act 2005. Scottish guidance on SEA also highlights the use of objectives within SEA and specifically the consideration of the water environment and also flooding within SEA (Scottish Executive, 2006; Scottish Government, 2013b).

\footnotetext{
${ }^{2}$ The Core Strategy is the primary Local Authority spatial planning document in England.

${ }^{3}$ Local Development Plans are the primary Local Authority spatial planning documents. Strategic Development Plans are a tier above Local Development Plans and are produced by four Strategic Development Planning Authorities in Scotland.
} 
Based on the review of literature presented in the introduction and the two supporting sections, Living with water: towards a new role for spatial planning and Enhancing delivery through SEA, it has been possible to identify certain key lines of enquiry for evaluating the consideration of flood risk in SA and SEA in England and Scotland. It is important to ask what reference is made to different approaches to flood management in SA and SEA, e.g. management of the whole system, risk and vulnerability, resilience and adaptation? Moreover, given the guidance in both England and Scotland to utilise objectives to drive assessment, it is key to consider how flooding is included within assessment objectives or assessment frameworks? Within this line of enquiry, and because of the subtle differences in the systems of SA and SEA operating in England and Scotland respectively, it is also important to explore how objectives for flood risk may differ in SA and SEA - whether SA encourages broader objectives, responding to its broader remit, or whether SEA encourages more environment focused objectives. Enquiry is of the conclusions and recommendations made to spatial planning related to flood management by SA and SEA in order to understand more about the outputs of SA and SEA and their influence on spatial planning and ultimately flooding.

\section{Methods}

Data presented here were gathered through case study analysis of individual applications of SA in England and SEA in Scotland within spatial planning. Data have been collected from the relevant environmental reports and planning documents produced in each case study. The cases (shown in Figure 1) were, in England, the SAs of the Black Country Joint Core Strategy and the Tunbridge Wells Borough Council Core Strategy, and, in Scotland, the SEAs of the Falkirk Council Local Plan and the Tay Strategic Development Planning Authority TAYplan.

Evidence collected from the case studies was analysed qualitatively using nVivo assistive software and followed the primary lines of enquiry identified as important as a result of the review of literature. The analytical approach taken was thematic coding or analysis, which involved coding of data and grouping codes into themes (Robson, 2011). Describing the benefits of thematic analysis Braun and Clarke (2006) highlighted its ability to provide a rich and detailed account of data, as well as communicating its complexity. The primary themes related to the different lines of enquiry identified from literature but were also sub-divided to allow for further detailed analysis. 


\section{Analysis of Case Studies}

Each of the case study assessments included reference to flood risk from multiple sources. As would be anticipated, variation exists in the cases with respect to the identification of sources of flood risk, e.g. the landlocked Black Country does not identify coastal flooding. However, there was variation in the attention given to, or visibility of, different sources of flooding, which perhaps demonstrates more recent and less practiced inclusion of pluvial, surface water or drainage related flood risk. For example, in the Black Country case the risk of flooding from storm water run-off and sewerage was prominently acknowledged. The Falkirk case meanwhile, clearly identified coastal and river flooding, but mentioned surface water run-off or sewerage by inference, noting the potential for new development to increase water run-off and certain known sewerage constraints which may potentially reduce water quality and ecological value of watercourses.

Considering the manner in which each assessment case included flood risk in their assessment framework, again there is variation in the prominence given to the topic. The provision for the consideration of flooding within each case study's assessment framework is shown in Table 1. It can be seen that not all of the case studies included a specific assessment objective concerning flooding; however, sub-objectives, related assessment questions and topic areas for consideration were identified in each of the cases. The Falkirk case included a specific objective related to flood risk, while the Tunbridge Wells and TAYplan cases included sub-objectives related to flooding. The Black Country case contained a SA objective related to climate change which raised issues of flood risk and also information around a series of Sustainability Topic Areas, one of which, 'Water and Soil', included information on flooding.

\section{TABLE 1}

Variation can be seen in the cases considered here, both with respect to the level of detail provided and the type of action the objectives might require. For example, both the Falkirk and TAYplan cases included objectives or sub-objectives aiming to reduce flood risk, while the sub-objective included in the Tunbridge Wells case suggested ambition is to not increase flood risk. In the Black Country case the Sustainability Topic Area and climate change objective provide little information on the ambition or direction proposed. This supports the findings of Carter et al. (2009) that assessment objectives for flood risk vary with respect to their position or visibility in the assessment, with some including a primary objective on flood risk and others having a sub-objective as part of a wider objective. 
The case studies predominantly made use of data obtained and presented through a previous assessment or collection process. Typically data originated from flood maps produced by the Environment Agency (in England) or the Scottish Environment Protection Agency which provide calculations of flood risk from rivers and seas in given time scales in demarcated areas. Several of the case studies also utilised SFRA (Black Country, Tunbridge Wells and TAYplan) to specifically consider flooding in their administrative areas. The use of data collected through a previous or parallel assessment process is common and has been suggested as able to enhance comprehensiveness, and time and cost efficiency (Vanclay, 2004). Tajima and Fischer (2013) noted that SA in England commonly incorporates multiple assessment processes, such as SFRA, which seek to establish the baseline or evidence base for a particular topic. However, as noted, the practice of broadening assessment scope has been suggested as leading to the marginalisation of certain issues (Morrison-Saunders \& Fischer, 2006). Overreliance on such flood risk data may also result in false precision, as described by Scott (2013), being ascribed to complex and uncertain data which requires specific knowledge to appropriately interpret it.

Evidence suggests that simplification of data and only brief description of uncertainty may occur. For example, the SA for the Black Country case cited Environment Agency flood risk data for certain spatial components with limited explanation of the uncertainty associated with the data, although uncertainty with regard to the influence of climate change on future flood risk was acknowledged;

\footnotetext{
According to the Environment Agency Flood Map, part of the area is prone to 'significant' flood risk, with the chance of flooding each year greater than $1.3 \%$ ( 1 in 75 ). This risk is likely to increase further as the effects of climate change become increasingly apparent, with implications for any proposed development. (Sustainability Appraisal of the Black Country Joint Core Strategy Preferred Options Report, 2008, p.34)
}

This emphasises the importance of the relationship between assessment and external flood risk data or assessments, such as SFRA; specifically highlighting the complexity of presenting this data and that uncertain data may be summarised and presented as overly precise. Moreover, given the role of SA and SEA to influence planning, the relationship between the recommendations of assessment and plan makers also becomes crucial (discussed in greater detail in the following section). It is therefore suggested that the network and flow of data between the various reports and actors provides potential space for inappropriate simplification, and that overreliance on uncertain data may result in false precision being attributed to flood risk data. 
The case studies also indicate that flood risk is described in relation to various different topics, broadly related to environmental, social and economic impacts. However, the cases also highlight that despite policy and guidance differences in terms of breadth of assessment between SA in England and SEA in Scotland, assessment practice is more blurred. For example, the TAYplan case identified environmental impacts such as habitat loss due to continued policies for engineered flood defences (SEA Scoping Report, p.25) and also cited the potential cost of future attenuation measures to protect development in the flood plain and more immediate impacts on the safety of people living in areas at risk of flooding (Environmental Report: TAYplan Main Issues Report, p.92). How one defines what constitutes an environmental, social or economic impact is, of course, debatable and in some respects moot given that flood risk itself is inextricably linked to social concerns. As described by Smith (2006), 'natural' disasters are often largely socially constructed with the impacts of disasters dependant on their location. What is not observed in the case studies is discussion of issues related to fairness or inequality of flood risk and environmental justice. Climate change and its potential to increase flood risk is acknowledged in all cases.

\section{Approach to flood risk management advocated}

The approach proposed and recommended for managing identified flood risk in each of the cases supports the findings of Richards et al. (2008) that approaches to flood risk management in local planning policies replicated national policy and failed to provide locally relevant responses. In the cases considered here the typical approaches recommended by assessment to be included in planning policy generally applied relevant national policy. Typical approaches recommended included:

i. avoiding development in identified areas of flood risk;

ii. applying the sequential or exception tests;

iii. requirements for SUDS;

iv. site specific flood risk assessments (Falkirk) and mitigation; and

v. engineered flood defences to protect certain settlements (Falkirk and TAYplan).

Each of the cases included recommendations for plans to adopt a presumption against development in areas of flood risk where possible. This was typically moderated through use of the sequential or exception tests to identify appropriate forms of development or exclude certain development from flood risk areas. Where development is to take place, the most common mitigation recommended took the form of SUDS and requirements for further site specific flood risk assessments. The Falkirk and TAYplan cases both included support for engineered flood defences to protect certain 
communities at risk from coastal flooding; in both instances proposals were to bolster defences protecting existing communities.

As discussed in the previous section, many of the recommendations necessarily build on the use of assessments of discrete areas labelled as at risk of flooding to various degrees, placing considerable importance on flood risk data and maps. As highlighted by Scott et al. (2013), as our understanding of flood risk and sources of flooding improves, the fewer concrete 'facts' we can reasonably claim to know. Scott et al. (2013) described a shift from precise to fuzzy data, yet also described the use of complex uncertain data being used with false precision. Indeed, taking into account the observation from assessment literature that greater information does not necessarily guarantee better decisions (Cashmore et al., 2008) one can see that there appears to be mismatch between our understanding of the flooding as complex and fuzzy and our assessment of flooding as quantifiable and precise.

Several of the typical responses observed in the cases examined here promote policy responses and mitigation measures which necessarily rely on and imply considerable confidence in assessments which demarcate distinct areas with and without out flood risk. Flood management which primarily takes the form of a presumption against development in areas of flood risk necessarily implies other areas are safe from flooding - an approach which other case study examples demonstrate to be lacking (see for example Douglas et al., 2010). Given that considerable flood risk is now recognised to be from intra-urban pluvial flooding (Evans et al., 2008), potentially exacerbated by increasing urbanisation and the effects of climate change (Pitt, 2008), it is also argued that there is a gap between our understanding of the problem as complex, and likely to increase and change; and the typical policy responses based around avoidance of specific flood risk areas.

The inclusion of site specific requirements for flood risk assessments to ensure suitable mitigation or site scale avoidance of flood risk areas similarly perpetuates the presumption that with greater information better decisions can be made. The focus in each case is on avoidance in order to control flood risk. However, in each case SUDS are routinely recommended for new development, potentially introducing greater resilience to various forms of flood risk. Nevertheless, evidence suggests that SA and SEA do not specifically promote a holistic, whole system response, or promote improved resilience to mitigate uncertainties in data.

\section{Main Findings}


From the evidence and analysis presented here it is possible to draw several conclusions relevant to both flood risk management and assessment, although it should be remembered that observations are situated within the context of each case study and therefore are not necessarily generalizable to the respective system at large.

Both systems, SA in England and SEA in Scotland, include consideration of flooding within their guidance for conducting assessment of spatial plans. It has been seen that flood risk is included in some form within the assessment framework of each case study, although this varies from consideration under general topics, to specific assessment sub-objectives and objectives related to flooding. It is considered that data presented here largely support the findings of Carter et al. (2009), that the consideration of flooding is often subsumed under other assessment objectives. It is not apparent from the evidence gathered, however, if this variation in visibility or position of SA and SEA objectives results in variation in the influence afforded to impacts, conclusions and recommendations related to flood risk.

The potential for marginalisation of topics through increased scope and generalisation of assessment is not observed and both SA and SEA are seen to include a mix of arguably environmental, social and economic impacts when considering flooding. It is argued that, in line with the view that natural disasters are in large part constructed socially, the consideration of flooding within assessment is inherently symptomatic of both SA and SEA incorporating, to some extent, environmental, social and economic impacts.

It is found that the use of complex data in SA and SEA resulting from parallel assessment processes, such as SFRA, introduces summarisation and potentially leads to false precision. This highlights the importance of data interpretation and the relationships between those preparing the plan and the various forms of assessment conducted which contribute to plan formulation.

Considering the manner in which the SA and SEA cases present the problem of flooding and make recommendations, it is found that assessment struggles to represent the complexity of flooding and flood risk. It is argued that assessment largely replicates national policy on flood risk rather than enabling personalised consideration of possible impacts and approaches to flood management.

\section{Conclusions and Future Developments}


To employ the language of 'tame and wicked' problems developed by Rittel and Webber (1973), the difficulty for planners aiming to develop 'solutions' to the wicked problems they face lies in first defining the problem. Considering the complexity of flooding seen through the review of literature and discussion of the policy context, defining and developing responses to flooding is multifaceted and relates intricately to many other problems. Building on the notion of tame and wicked problems, Grint (2010) described our predisposition for constructing flawed, but elegant, solutions to tame or wicked problems. The responses tend to be simple 'solutions' which in part replicate the problem, or delay decision making in order to collect more information to gain greater understanding (Grint, 2010). Moreover, assessment literature acknowledges the historic tendency for assessment processes to be based on a rationalist notion that simply acquiring information can produce better decisions. It is concluded that the assessment cases considered, in part, fall victim to the pit falls described by Grint when trying to tackle flooding by suggesting elegant solutions and calling for greater information. The assessment cases considered here rely on complex data or parallel assessment processes (such as SFRA), promote generic attenuation approaches and call for greater information at a lower or site specific scale rather than enabling the generation of tailored approaches to flood management.

Considering possible future developments in light of the case study analysis and wider discussion of literature it is considered that there is a strong case to argue for the potential of SA and SEA to contribute to flood management in spatial planning. However, there are several shortcomings identified in the case studies which require further examination and research, particularly the potential for reliance on probabilistic calculations of flood risk areas to produce false precision. It is also considered that there remains a largely untapped potential for assessment tools to broaden the consideration of flood risk to incorporate multiple perspectives, such as whole system management, risk and vulnerability, resilience and adaptation; to tackle issues of fairness and environmental justice; and to contribute to the generation of creative and tailored approaches to flood management in spatial planning.

\section{Acknowledgements}

This paper was developed as part of a Japan-UK joint workshop, 'Policy Integration between Environmental Assessment and Disaster Management'. We are grateful to organisers of this workshop which was supported by the University of Liverpool, Chiba University of Commerce, the Economic and Social Research Council, and the Japan Society for the Promotion of Science. The 
constructive comments of the two anonymous reviewers were also instrumental in improving this paper.

\section{References}

Baan, P.J.A. \& Klijn, F. (2004). 'Flood risk perception and implications for flood risk management in the Netherlands', International Journal of River Basin Management, vol. 2, no. 2, pp. 113122.

Bond, A.J. \& Morrison-Saunders, A. (2009). 'Sustainability appraisal: jack of all trades, master of none?', Impact Assessment \& Project Appraisal, vol. 27, no. 4, pp. 321-329.

Braun, V. \& Clarke, V. (2006). 'Using thematic analysis in psychology', Qualitative Research in Psychology, vol. 3, no. 2, pp. 77-101.

Brown, A.L. \& Therivel (2000). 'Principles to guide the development of strategic environmental assessment methodology', Impact Assessment and Project Appraisal, vol. 18, pp. 183-189.

Carter, J.G., White, I. \& Richards, J. (2009). 'Sustainability appraisal and flood risk management', Environmental Impact Assessment Review, vol. 29, no. 1, pp. 7-14.

Carter, J.G., Wood, C.M. \& Baker, M. (2003). 'The Environmental Appraisal of National Park Management Plans in England and Wales', Journal of Environmental Planning and Management, vol. 46, pp. 271-288.

Cashmore, M., Bond, A. \& Cobb, D. (2008). 'The role and functioning of environmental assessment: Theoretical reflections upon an empirical investigation of causation', Journal of Environmental Management, vol. 88, no. 4, pp. 1233-1248.

Committee on Climate Change (2012). Climate change - is the UK preparing for flooding and water scarcity?: Adaptation Sub-Committee Progress Report 2012, Committee on Climate Change, London.

Davoudi, S., Crawford, J. \& Mehmood, A. (2009). Planning for climate change : strategies for mitigation and adaptation for spatial planners, Earthscan, London.

Dawson, R.J., Speight, L., Hall, J.W., Djordjevic, S., Savic, D. \& Leandr, J. (2008). 'Attribution of flood risk in urban areas', Journal of Hydroinformatics, vol. 10, no. 4, pp. 275-288.

Department for Communities and Local Government (DCLG) (2009a). CLG Plan making manual: Sustainability Appraisal Department for Communities and Local Government, London.

Department for Communities and Local Government (DCLG) (2009b). Planning Policy Statement 25: Development and Flood Risk Practice Guide, Department for Communities and Local Government, London.

Department for Communities and Local Government (DCLG) (2012). National Planning Policy Framework, Department for Communities and Local Government, London.

Department for Communities and Local Government (DCLG) (2014). National Planning Practice Guidance: Strategic environmental assessment and sustainability appraisal, Department for Communities and Local Government, London.

de Bruijn, K.M. (2004). 'Resilience and flood risk management', Water Policy, vol. 6, no. 1, pp. 5366.

Department for Environment, Food and Rural Affairs (DEFRA) (2005). Making space for water: Taking forward a new Government strategy for flood and coastal erosion risk management in England, Department for Environment, Food and Rural Affairs, London.

Douglas, I., Garvin, S., Lawson, N., Richards, J., Tippett, J. \& White, I. (2010). 'Urban pluvial flooding: a qualitative case study of cause, effect and nonstructural mitigation', Journal of Flood Risk Management, vol. 3, no. 2, pp. 112-125.

Elling, B. (2008). Rationality and the environment: Decision-making in Environmental Politics and Assessment, Earthscan, London. 
EM-DAT (2010). The OFDA/CRED International Disaster Database [Online], Université Catholique de Louvain, Available from: http://www.emdat.be/ (Accessed: 10/04/2014).

European Environment Agency (2010). Mapping the impacts of natural hazards and technological accidents in Europe: An overview of the last decade Report Number 13/2010, European Environment Agency, Luxembourg.

Evans, E.P., Simm, J.D., Thorne, C.R., Arnell, N.W., Ashley, R.M., Hess, T.M., Lane, S.N., Morris, J., Nicholls, R.J., Penning-Rowsell, E.C., Reynard, N.S., Saul, A.J., Tapsell, S.M., Watkinson, A.R. \& Wheater, H.S. (2008). An update of the Foresight Future Flooding 2004 qualitative risk analysis, London.

Feyen, L., Dankers, R., Bódis, K., Salamon, P. \& Barredo, J. (2012). 'Fluvial flood risk in Europe in present and future climates', Climatic Change, vol. 112, no. 1, pp. 47-62.

Fischer, T. (2007). Theory and Practice of Strategic Environmental Assessment: towards a more systematic approach, Earthscan, London.

Gibson, R.B. (2006). 'Beyond the Pillars: Sustainability Assessment as a Framework for Effective Intergration of Social, Economic and Ecological Considerations in Significant DecisionMaking', Journal of Environmental Assessment Policy \& Management, vol. 8, no. 3, pp. 259280.

Government Office for Science (2004). Foresight: Future Flooding, Government Office for Science, London.

Greiving, S., Fleischhauer, M. \& Wanczura, S. (2006). 'Management of natural hazards in Europe: The role of spatial planning in selected EU member states', Journal of Environmental Planning and Management, vol. 49, no. 5, pp. 739-757.

Grint, K. (2010). 'The cuckoo clock syndrome: addicted to command, allergic to leadership', European Management Journal, vol. 28, no. 4, pp. 306-313.

Hall, J., Meadowcroft, I., Sayers, P. \& Bramley, M. (2003). 'Integrated Flood Risk Management in England and Wales', Natural Hazards Review, vol. 4, no. 3, pp. 126-135.

Hall, J. \& Solomatine, D. (2008). 'A framework for uncertainty analysis in flood risk management decisions', International Journal of River Basin Management, vol. 6, no. 2, pp. 85-98.

Hardaker, P. \& Collier, C. (2013). 'Flood Risk from Extreme Events (FREE) - a National Environment Research Council directed programme', Quarterly Journal of the Royal Meteorological Society, vol. 139, no. 671, pp. 281-281.

Holling, C.S. (2001). 'Understanding the Complexity of Economic, Ecological, and Social Systems', Ecosystems, vol. 4, no. 5, pp. 390-405.

Howe, J. \& White, I. (2004). 'Like a Fish Out of Water: The Relationship between Planning and Flood Risk Management in the UK', Planning Practice \& Research, vol. 19, no. 4, pp. 415-425.

Jackson, T. \& Illsley, B. (2007). 'An analysis of the theoretical rationale for using strategic environmental assessment to deliver environmental justice in the light of the Scottish Environmental Assessment Act', Environmental Impact Assessment Review, vol. 27, no. 7, pp. 607-623.

Johnson, C., Penning-Rowsell, E. \& Parker, D. (2007). 'Natural and imposed injustices: the challenges in implementing 'fair' flood risk management policy in England', Geographical Journal, vol. 173, no. 4, pp. 374-390.

Johnson, C.L. \& Priest, S.J. (2008). 'Flood Risk Management in England: A Changing Landscape of Risk Responsibility?', International Journal of Water Resources Development, vol. 24, no. 4, pp. 513-525.

Klijn, F., van Buuren, M. \& van Rooij, S.A.M. (2004). 'Flood-risk Management Strategies for an Uncertain Future: Living with Rhine River Floods in The Netherlands?', AMBIO: A Journal of the Human Environment, vol. 33, no. 3, pp. 141-147.

Kundzewicz, Z.W., Pińskwar, I. \& Brakenridge, G.R. (2012). 'Large floods in Europe, 1985-2009', Hydrological Sciences Journal, vol. 58, no. 1, pp. 1-7.

Larsen, S.V., Kørnøv, L. \& Driscoll, P. (2013). 'Avoiding climate change uncertainties in Strategic Environmental Assessment', Environmental Impact Assessment Review, vol. 43, pp. 144-150.

Merz, B., Hall, J., Disse, M. \& Schumann, A. (2010). 'Fluvial flood risk management in a changing world', Natural Hazards \& Earth System Sciences, vol. 10, no. 3, pp. 509-527. 
Morrison-Saunders, A. \& Fischer, T. (2006). 'What is wrong with EIA and SEA anyway? A sceptic's perspective on sustainability assessment', Journal of Environmental Assessment Policy and Management, vol. 8, no. 1, pp. 19-39.

Mostert, E. \& Junier, S.J. (2009). 'The European flood risk directive: challenges for research', Hydrology \& Earth System Sciences Discussions, vol. 6, no. 4, pp. 4961-4988.

Noble, B. \& Christmas, L. (2008). 'Strategic Environmental Assessment of Greenhouse Gas Mitigation Options in the Canadian Agricultural Sector', Environmental Management, vol. 41, no. 1, pp. 64-78.

Office of the Deputy Prime Minister (ODPM) (2005). A practical guide to the strategic environmental assessment directive: practical guidance on applying European directive 2001/42/EC "on the assessment of the effects of certain plans and programmes on the environment", Office of the Deputy Prime Minister, London.

Pitt, M. (2008). Learning lessons from the 2007 floods, Cabinate Office, London.

Pope, J., Annandale, D. \& Morrison-Saunders, A. (2004). 'Conceptualising sustainability assessment', Environmental Impact Assessment Review, vol. 24, no. 6, pp. 595-616.

Posas, P.J. (2011). 'Exploring climate change criteria for strategic environmental assessments', Progress in Planning, vol. 75, no. 3, pp. 109-154.

Pottier, N., Penning-Rowsell, E., Tunstall, S. \& Hubert, G. (2005). 'Land use and flood protection: contrasting approaches and outcomes in France and in England and Wales', Applied Geography, vol. 25, no. 1, pp. 1-27.

Richards, J., White, I. \& Carter, J. (2008). 'Local planning practice and flood risk management in England: is there a collective implementation deficit?', Environnement Urbain / Urban Environment, vol. 2, pp. 11-20.

Rittel, H.W.J. \& Webber, M.M. (1973). 'Dilemmas in a general theory of planning', Policy Sciences, vol. 4, no. 2, pp. 155-169.

Robson, C. (2011). Real world research: a resource for users of social research methods in applied settings, 3rd edn, Wiley-Blackwell, Oxford.

Rosenzweig, C., Casassa, G., Karoly, D.J., Imeson, A., Liu, C., Menzel, A., Rawlins, S., Root, T.L., Seguin, B. \& Tryjanowski, T. (2007). Assessment of observed changes and responses in natural and managed systems, in M.L. Parry, O.F. Canziani, J.P. Palutikof, P.J. van der Linden \& C.E. Hanson (eds), Climate Change 2007: Impacts, Adaptation and Vulnerability. Contribution of Working Group II to the Fourth Assessment Report of the Intergovernmental Panel on Climate Change, Cambridge University Press, Cambridge, UK, pp. 79-131.

Sadler, B. \& Verheem, R. (1996). Strategic Environmental Assessment: Status, challenges and future directions, Ministry of Housing Spatial Planning and the Environment, The Hague.

Samuels, P., Klijn, F. \& Dijkman, J. (2006). 'An analysis of the current practice of policies on river flood risk management in different countries', Irrigation and Drainage, vol. 55, no. S1, pp. S141-S150.

Scott, M., White, I., Kuhlicke, C., Steinführer, A., Sultana, P., Thompson, P., Minnery, J., O'Neill, E., Cooper, J., Adamson, M. \& Russell, E. (2013). 'Living with flood risk', Planning Theory \& Practice, vol. 14, no. 1, pp. 103-140.

Scottish Executive (2006). Strategic Environmental Assessment Tool Kit, Scottish Executive, Edinburgh.

Scottish Government (2013a). Scottish Planning Policy: Consultation Draft, Scottish Government, Edinburgh.

Scottish Government (2013b). Strategic Environmental Assessment Guidance, Scottish Government, Edinburgh.

Scrase, J. \& Sheate, W. (2002). 'Integration and integrated approaches to assessment: what do they mean for the environment?', Journal of Environmental Policy \& Planning, vol. 4, no. 4, pp. 275 - 294.

Sheate, W., R. , Dagg, S., Richardson, J., Aschemann, R., Palerm, J. \& Steen, U. (2003). 'Integrating the environment into strategic decision-making: conceptualizing policy SEA', European Environment, vol. 13, no. 1, pp. 1-18. 
Smith, N. (2006). There's No Such Thing as Natural Disasters, Understanding Katrina: Perspectives from the social sciences, Social Science Research Council, http://understandingkatrina.ssrc.org/Smith/

Smith, S. \& Sheate, W. (2001). 'Sustainability appraisal of English regional plans: incorporating the requirements of the EU Strategic Environmental Assessment Directive', Impact Assessment and Project Appraisal, vol. 19, pp. 263-276.

Tajima, R. \& Fischer, T.B. (2013). 'Should different impact assessment instruments be integrated? Evidence from English spatial planning', Environmental Impact Assessment Review, vol. 41, pp. 29-37.

Therivel, R. (2004). Strategic environmental assessment in action, Earthscan, London.

Therivel, R., WIlson, E., Thompson, S., Heaney, D. \& Pritchard, D. (1992). Strategic Environmental Assessment Earthscan, London.

Tunstall, S., Johnson, C. \& Rowsell, E. (2004). '28. Flood Hazard Management in England and Wales: From Land Drainage to Flood Risk Management', Water and Energy Abstracts, vol. 14, no. 2, pp. 447-454.

UK Government (2004). Planning and Compulsory Purchase Act 2004, The Stationary Office, London.

Vanclay, F. (2004). 'The Tripple Bottom Line and Impact Assessment: How do TBL, EIA, SIA, SEA and EMS relate to each other?', Journal of Environmental Assessment Policy \& Management, vol. 6, no. 3, pp. 265-288.

Vis, M., Klijn, F., De Bruijn, K.M. \& Van Buuren, M. (2003). 'Resilience strategies for flood risk management in the Netherlands', International Journal of River Basin Management, vol. 1, no. 1, pp. 33-40.

Walker, G. \& Burningham, K. (2011). 'Flood risk, vulnerability and environmental justice: Evidence and evaluation of inequality in a UK context', Critical Social Policy, vol. 31, no. 2, pp. 216240.

Werritty, A., Houston, D., Ball, T., Tavendale, A. \& Black, A. (2007). Exploring the Social Impacts of Flood Risk and Flooding in Scotland, Scottish Executive, Edinburgh.

Wheater, H. \& Evans, E. (2009). 'Land use, water management and future flood risk', Land Use Policy, vol. 26, pp. S251-S264.

White, I. (2010). Water and the city: risk, resilience and planning for a sustainable future, Routledge, London.

White, I. \& Richards, J. (2007). 'Planning policy and flood risk: The translation of national guidance into local policy', Planning Practice \& Research, vol. 22, no. 4, pp. 513-534.

Wilby, R.L., Beven, K.J. \& Reynard, N.S. (2008). 'Climate change and fluvial flood risk in the UK: more of the same?', Hydrological Processes, vol. 22, no. 14, pp. 2511-2523.

Wilson, E. (2007). 'Comment: Response to Planning Theory and Practice 2006, 7(2), Interface: Is the Issue of Climate Change too Big for Spatial Planning?', Planning Theory \& Practice, vol. 8, no. 1, pp. 125-127.

Wilson, E. \& Piper, J. (2010). Spatial planning and climate change, Routledge, London. 


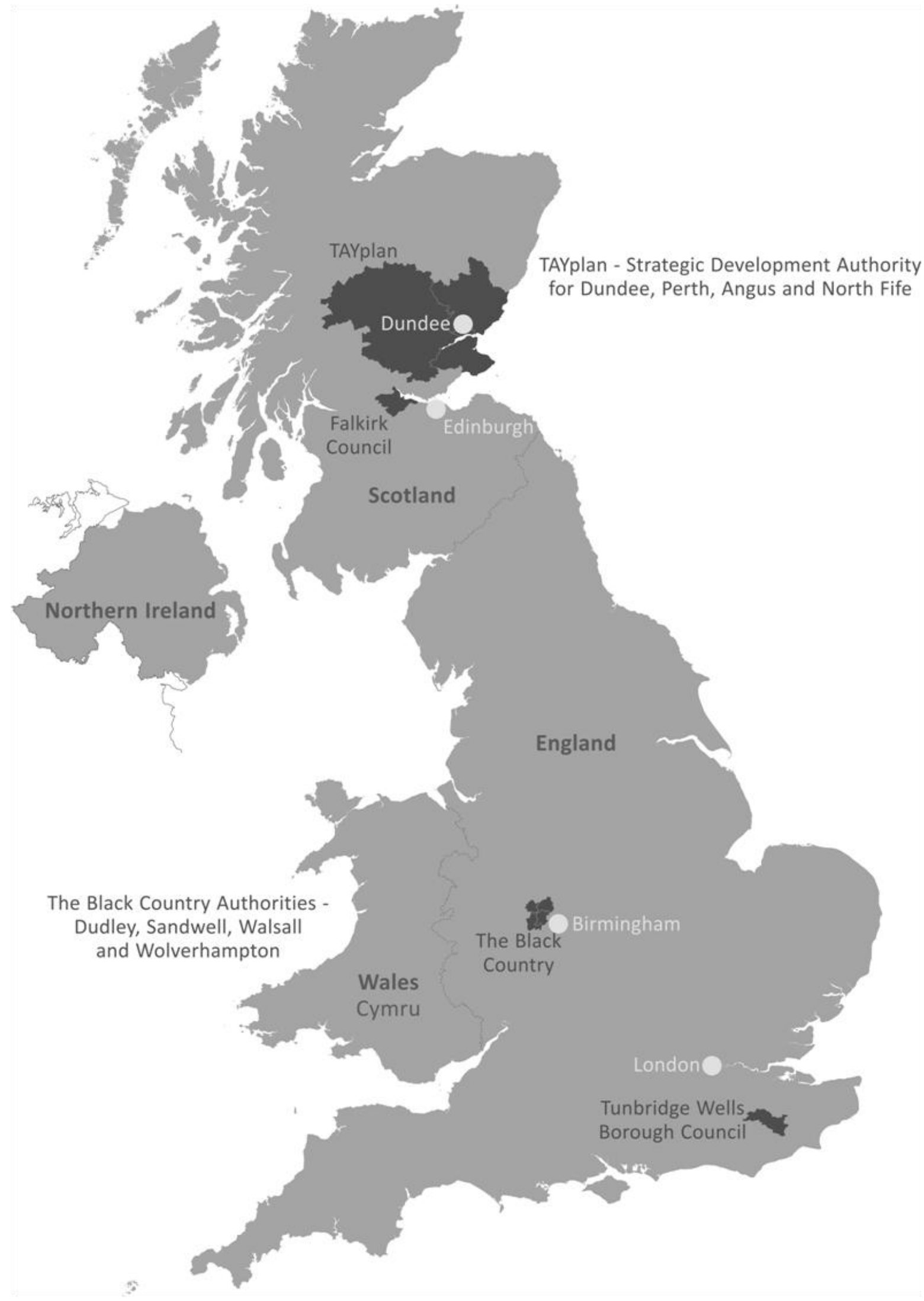

Figure 1: Location of the case studies 


\begin{tabular}{|c|c|c|c|c|}
\hline & $\begin{array}{l}\text { Black Country Joint } \\
\text { Core Strategy SA }\end{array}$ & $\begin{array}{l}\text { Tunbridge Wells } \\
\text { Borough Core } \\
\text { Strategy SA }\end{array}$ & $\begin{array}{l}\text { Falkirk Council } \\
\text { Local Plan SEA }\end{array}$ & $\begin{array}{l}\text { TAYplan Strategic } \\
\text { Development Plan } \\
\text { SEA }\end{array}$ \\
\hline $\begin{array}{l}\text { Assessment } \\
\text { objective }\end{array}$ & & & $\begin{array}{l}\text { SEA Objective: } \\
\text { 'Reduce flood risk.' }\end{array}$ & \\
\hline $\begin{array}{l}\text { Assessment } \\
\text { Sub- } \\
\text { objective }\end{array}$ & & $\begin{array}{l}\text { SA Sub-objective: } \\
\text { 'Will it prevent } \\
\text { inappropriate } \\
\text { development in areas } \\
\text { at risk of flooding?' }\end{array}$ & & $\begin{array}{l}\text { Assessment } \\
\text { Question: 'Will it } \\
\text { reduce the number of } \\
\text { properties, and } \\
\text { infrastructure, at risk } \\
\text { from flooding?' }\end{array}$ \\
\hline $\begin{array}{l}\text { Related } \\
\text { assessment } \\
\text { objective or } \\
\text { topic area }\end{array}$ & $\begin{array}{l}\text { SA Objective: 'Plan } \\
\text { for the anticipated } \\
\text { different levels of } \\
\text { climate change.'* } \\
\text { Sustainability Topic } \\
\text { Area: 'Water and } \\
\text { Soil' - includes } \\
\text { flooding. }\end{array}$ & & & \\
\hline Source & $\begin{array}{l}\text { Sustainability } \\
\text { Appraisal of the } \\
\text { Black Country Joint } \\
\text { Core Strategy: } \\
\text { Publication SA } \\
\text { Report, p. } 26 \& 13\end{array}$ & $\begin{array}{l}\text { Final Sustainability } \\
\text { Appraisal Report, p. } \\
17 \text { \& Sustainability } \\
\text { Appraisal Scoping } \\
\text { Report, p. } 42\end{array}$ & $\begin{array}{l}\text { Falkirk Council } \\
\text { Local Plan Post } \\
\text { Adoption Strategic } \\
\text { Environmental } \\
\text { Assessment } \\
\text { Statement, p. } 19\end{array}$ & $\begin{array}{l}\text { Environmental } \\
\text { Report TAYplan } \\
\text { Main Issues Report, } \\
\text { p. } 45\end{array}$ \\
\hline \multicolumn{5}{|c|}{$\begin{array}{l}\text { *Discussion related to this SA Objective considers how climate change may exacerbate existing issues of storm } \\
\text { water run-off and sewerage flooding. Source: Sustainability Appraisal of the Black Country Joint Core Strategy: } \\
\text { Publication SA Report, p. } 30 \text {. }\end{array}$} \\
\hline
\end{tabular}




\section{FLOOD MANAGEMENT CONSIDERATION IN SUSTAINABILITY APPRAISAL AND STRATEGIC ENVIRONMENTAL ASSESSMENT IN ENGLAND AND SCOTLAND}

\begin{tabular}{|c|c|c|}
\hline \multicolumn{2}{|c|}{ Reviewer 1} & \multirow[b]{2}{*}{ How changed } \\
\hline$\#$ & Comment & \\
\hline 1 & Not whole of UK considered & $\begin{array}{l}\text { Changed to clarify focus on England and } \\
\text { Scotland }\end{array}$ \\
\hline 2 & $\begin{array}{l}\text { Lack of clear coherent line of argument } \\
\text { developed through literature } \\
\text { review/summary. Some points distract from } \\
\text { argument. Reader is not led to case study } \\
\text { analysis and conclusions. }\end{array}$ & $\begin{array}{l}\text { The literature has been reorganised to more } \\
\text { clearly introduce and demarcate the } \\
\text { different areas of literature. Specifically } \\
\text { broken down into approaches to flood } \\
\text { management, the role of spatial planning } \\
\text { and the possible contribution of SA/SEA to } \\
\text { this. }\end{array}$ \\
\hline 3 & De-clutter literature. & $\begin{array}{l}\text { The organisation has been changed. Sections } \\
\text { now cluster more closely related areas of } \\
\text { literature together and different topics are } \\
\text { separated with sub-headings to avoid } \\
\text { confusion and a perception of clutter. }\end{array}$ \\
\hline 4 & Carefully construct conceptual framework. & $\begin{array}{l}\text { The re-structured the literature more clearly } \\
\text { and better explains the premise and } \\
\text { conceptual basis for this paper. }\end{array}$ \\
\hline 5 & $\begin{array}{l}\text { Draw out clearer messages about the new } \\
\text { responsibilities and approach to flood risk of } \\
\text { spatial planning. } \\
\text { - Identify/elaborate key role for } \\
\text { planners dealing with flooding (p.5) } \\
\text { - More detail on why planning is } \\
\text { important - relate to engineering and } \\
\text { other solutions / problems of false } \\
\text { precision etc. }\end{array}$ & $\begin{array}{l}\text { Added detail on the areas of planning which } \\
\text { have been identified as areas which can have } \\
\text { a significant impact on flood risk } \\
\text { management. }\end{array}$ \\
\hline 6 & $\begin{array}{l}\text { Recent changes are to policy not necessarily } \\
\text { to practice. }\end{array}$ & $\begin{array}{l}\text { Wording changed to make clear identified } \\
\text { changes are to policy. }\end{array}$ \\
\hline 7 & $\begin{array}{l}\text { More clarity/detail of role of planning in } \\
\text { 'whole system' approach to flood risk. }\end{array}$ & See response to comment 5 . \\
\hline 8 & Jump to discussion of SEA/SA (p.5). & $\begin{array}{l}\text { Added paragraph about the role of SA/SEA } \\
\text { upfront, linked to the discussion of the role } \\
\text { of planning (p. 2). }\end{array}$ \\
\hline 9 & Pitt Review2 - as footnote (p.6). & Changed \\
\hline 10 & $\begin{array}{l}\text { Case study description and analysis mixed. } \\
\text { Analysis lacks structure - series of unrelated } \\
\text { points. }\end{array}$ & $\begin{array}{l}\text { The case study analysis is more structured to } \\
\text { develop towards main findings and } \\
\text { conclusions. }\end{array}$ \\
\hline 11 & $\begin{array}{l}\text { Table could be further developed, contains } \\
\text { little information to support your argument } \\
\text { (p.12). }\end{array}$ & $\begin{array}{l}\text { The table is designed only to illustrate and } \\
\text { support the discussion of the inclusion of } \\
\text { flood risk in SA and SEA objectives. It pulls } \\
\text { together the main way assessment } \\
\text { frameworks include flood risk highlighting } \\
\text { the different labels given. The detail of this } \\
\text { variation, in terms of visibility and implied }\end{array}$ \\
\hline
\end{tabular}




\begin{tabular}{|c|c|c|}
\hline & & $\begin{array}{l}\text { strength of objectives is discussed in greater } \\
\text { detail in the text. }\end{array}$ \\
\hline 12 & Paragraph indented (p.12). & Changed. \\
\hline \multicolumn{3}{|c|}{ Reviewer 2} \\
\hline & Comment & How changed \\
\hline 1 & $\begin{array}{l}\text { Consider splitting the conclusions section into } \\
\text { two; key findings and main conclusions (with } \\
\text { some consideration of how to tackle } \\
\text { problems). }\end{array}$ & $\begin{array}{l}\text { Last section has been split into main findings, } \\
\text { and conclusions and future directions. }\end{array}$ \\
\hline
\end{tabular}

